\title{
THE ROLE OF ALTERED STATES IN THE FORMATION OF WORLDVIEWS
}

\author{
Kononenko O. I., Shandruk S. K.
}

\section{INTRODUCTION}

The problem of consciousness has attracted mankind for many centuries. It was studied by philosophy, starting with ancient philosophers and ending with modern times, theology, as well as psychology and psychiatry. The variety and complexity of the phenomenon of consciousness, the difference in the forms of its manifestation, the multiplicity of its components and functions led to the formation of various methodological approaches to its analysis. One of these approaches is to study the states of human consciousness, their characteristics, functions and interactions, and is aimed at studying the phenomenon of consciousness through different states in which it may exist.

The study and development of spiritual and religious practices that change the state of human consciousness have long been considered by the Eastern cultural tradition as one of the ways of spiritual and moral improvement, within the framework of the Western tradition to the changed states of consciousness (WSS) have been appealing since the times of ancient Greece. However, despite the ever-increasing interest in the changed states of consciousness, and in the presence of a significant number of works devoted to this topic, only in the twentieth century. The phenomenon of changed states of consciousness has become widespread and has become the subject of a prof ound and thorough study.

Now this phenomenon has spread even more strongly and manifests itself at different levels. Walking through the city you can see posters and billboards that of fer to change the level of consciousness with the help of practices such as meditation or yoga, in medical institutions doctors recommend the use of meditative practices to prevent cardiovascular diseases, psychotherapy used techniques of hypnosis, and the power of the vast majority of countries are actively engaged in an open fight against substances that change the state of human consciousness. (Despite this struggle, the number of people who used such substances around the world in 2015 exceeded 247 million people ${ }^{1}$, and this number

${ }^{1}$ United Nations Office on Drugs and Crime. World Drug Report 2016. Sales No. E.16.XI.7. New York : United Nations publication, 2016. 174 p. URL:http://www.unodc.org/doc/wdr2016/WORLD_DRUG_ REPORT_2016_web.pdf. (дата звернення: 12.05.2019). 
continues to rise). Some researchers are even inclined to consider computer games, the audience of which is computed by hundreds of millions, one way to achieve changed states of consciousness ${ }^{2}$.

Thus, today the phenomenon of changed states of consciousness is an object of interest both in scientific and non-scientific circles: regularly held conferences and congresses devoted to changed states of consciousness; neurophysiologists are engaged in researches of the human brain in the changed states of consciousness; in the media space there are separate forums and communities in which tens of thousands of people are actively discussing changed states of consciousness and various ways to achieve them.

Together with the altered states of consciousness, worldviews are also of obvious interest in modern society. Currently, as never before in history, a person has access to virtually unlimited amount of information - and views on the history of the native person of culture, his religion and values, grafted from the moment of birth, may undergo significant changes, by virtue of only one familiarity with information about other traditions and religions. The style of thinking inherent in one or another culture, which used to be an essential component of the worldview as a reflection of the world and a value relation to it, no longer seems so fundamental, since a modern person can completely and freely familiarize itself with the inheritance, including spiritual, other peoples and cultural formations.

The reasons for the formation of ideological settings can be various factors, such as native language, maturation age, education and training of a person, her experience in acquaintance with other cultural traditions, as well as the experience of direct interaction with the sphere of spiritual, the areas of individual and collective unconscious, which is obtained, in including, and because of the changed states of consciousness.

At this time, there is a large number of works, in which the features, structure, properties of the changed states of consciousness, their relations to the mystical and religious experience are described in great detail. Also in psychological and philosophical literature there are detailed descriptions and characteristics of worldviews and attitudes. However, the correlation of changed states of consciousness with ideological settings, as well as the degree of their relationship, is not sufficiently identified.

\footnotetext{
${ }^{2}$ Кулешов Р.Н. Виртуальная реальность компьютерных игр как феномен ИСС. Психотехники $u$ измененные состояния сознания / Отв. ред. С. В. Пахомов. Санкт-Петербург : РХГА, 2015. URL:http://www.yoga.net.ua/filials.php?action=shownews\&id=1421\&fid=34_(дата звернення: 12.05.2019).
} 


\section{The concept of "consciousness", "changed states of consciousness" and "worldviews"}

Scientific concepts, as you know, are of ten polyfunctional, and depending on the circumstances and place of their use may have different meanings. Such, for example, is the situation with the term "changed states of consciousness", which is quite common in the modern scientific and non-scientific world. Differences in the understanding and interpretation of this concept can lead not only to its polysemy at all levels (since the changed states of consciousness are also studied in a wide range of disciplines), but at all to the possible loss of terminological complexity. This will be discussed separately below.

On the other hand, the precise definition of the term "worldview settings" does not occur either in the Ukrainian-language, or in Russianlanguage, or in the English-language literature. In most cases, in the scientific literature, the concept of "worldview settings" is reduced to the concept of "worldview", which, in essence, is unreasonable generalization. In this regard, in this study a new interpretation of this term will be proposed, which will be correlated with the concepts of "worldview" and "setting" in the broadest sense of these words.

Consciousness has been the subject of scientific study for many centuries. It is one of the basic concepts in many disciplines - philosophy, psychology, sociology, and in the broadest sense means "the highest level of mental activity of man as a social being". In each of the presented disciplines the question of consciousness takes its special place. Thus, in philosophy, the question of the relation of consciousness to being is one of the key, because acting as a property of highly organized matter (brain), worldview is the awareness of being, that is, the subjective imprint, the image of the objective world, which is presented in the form of subjective reality. In terms of epistemological - consciousness acts as an ideal as the opposite of the material. Historically, consciousness is not always differentiated as somewhat separate from the material substance. In the early stages of the development of philosophical knowledge, consciousness (and mental processes) were identified with material or abstract, but not contradicted by the first and not separated from it.

Psychology examines consciousness as a property of the psyche, the ability to reflect the objective stable properties of objective reality ${ }^{3}$. One of the important functions of consciousness, in this case, is the ability

Леонтьев А.Н. Эволюция психики. Воронеж : Издательство НПО «МОДЭК», 1999. 416 c. - C. 213. 
to imagine the construction and foresight of the activity and consequences of this activity, as well as control of human behavior, the possibility of understanding what is happening, firstly, in its own psychic world, and secondly, in the surrounding reality.

Thus, consciousness is a complex systemic system that has different levels, and awareness of these levels manifests itself in knowledge about the degree of clarity of consciousness, in other words, about its states. These degrees determine the orientation in the surrounding world, the feeling of empirical individuality, isolation from the outside world, as well as the nature of the experience of man with his attitude to reality. In more detail, the question of determining the states of consciousness will be considered below.

In the case of the term "changed states of consciousness", we are confronted with a multitude of different definitions, each of which only in one degree or another can cover and describe the whole wide range of states that we, while intuitively, call modified ones. The term "changed states of consciousness" can be called rather conditional, as experts from different areas tend to invest in its definition and interpretation are far from the same meanings. However, there is the definition of changed states of consciousness, which is considered to be classical. This is the definition of the German psychologist Arnold Ludwig, according to which the altered state of consciousness is, in essence, any psychological state that can be caused by both physiological, psychological and pharmacological means, and whose feature is that it is "subjectively recognized by the person itmself (or his objective observer) as a rather pronounced deviation of the subjective experience or mental functioning from his general normal state, when he does not sleep and is in a vigilant consciousness. Such deviations can be represented by a greater than usual, concern for internal sensations or imaginary processes, a change in the formal characteristics of thinking and the weakening of the ability to test reality of varying degrees" ${ }^{\text {. }}$

From this definition we can conclude that the changed states of consciousness presuppose the presence of a "normal" state, and different from "changed" states. For a deeper understanding of the ratio of changed states of consciousness and "normal" state of consciousness, it is necessary to turn to approaches in modern psychology, which of fer their model of consciousness and the relationship of changed states of consciousness to the so-called "Basic" state. There are several

\footnotetext{
${ }^{4}$ Тарт Ч. Измененные состояния сознания . Ульяновск : «Ульяновский Дом Печати», 2003. 537 с.
} 
approaches to describing the changed states of consciousness and how these states correlate and interact: it is a continuum model of consciousness, discrete, and discrete-continuum (adjacent).

One of the main representatives of the continual approach, C. Martindale, was the concept of continuous (continual) states of consciousness, according to which states of consciousness are systems that are relatively stable and orderly, located on the interval between opposite states of consciousness - vivacity on the one hand, and unconscious on the other. K. Martindale of fers a one-dimensional “axis", along which all aspects of consciousness change, differing only from the position on this axis of regression. At its upper point is the usual, initial state of consciousness, and along it, in the direction of regression, there are all sorts of WSS that continuously pass ${ }^{5}$.

The opposing views on the nature of consciousness had a representative of the discrete approach, Charles Tarte, pioneer of studies of altered states of consciousness, which, with his anthology, "Changed states of consciousness" introduced into the wide scientific circulation of the study of altered states of consciousness ${ }^{6}$. His approach is based on the model of consciousness as a complexly organized system design. Disk state of the state of consciousness (DZSS) is a new system with unique properties and characteristics that has a changed structure in relation to the initial state ${ }^{7}$. This system has a number of psychological functions, the implementation of which provides it with stability and durability with significant changes in individual systems. All discrete changed states of consciousness qualitatively differ from one another, and are constantly changing: that for one person there are altered states of consciousness, for another one can be an everyday experience. Transition from socalled the basic state of consciousness to a discrete, changed state of consciousness occurs jump-like and is accompanied by a rupture of the interactions of mental subsystems with their subsequent transformation, which leads to the construction of a new structure of consciousness. In the future, according to a similar scenario, there is a transition to the next discrete, changed state of consciousness.

A special interest in the study of altered states of consciousness is the study of transpersonal psychology, one of the founders of which,

\footnotetext{
${ }^{5}$ Психология сознания / Сост. и общая редакция Л. В. Куликова. Санкт-Петербург : Питер, 2001. $480 \mathrm{c}$.

${ }^{6}$ Спивак Д.Л. Изменённые состояния сознания: психология и лингвистика. Санкт-Петербург : «Издательский Дом Ювента»; Филологический ф-т СПбГУ, 2000. 296 с.

7 Тарт Ч. Системный подход к сознанию. Пути за предель эго / Под ред. Р. Уолша и Ф. Воон. Москва : Открытый Миp, 1996. URL: http://www.klex.ru/7wt (дата звернення: 12.05.2019).
} 
S. Grof f, was proposed a new cartography of consciousness. According to him, consciousness has a complex multi-level structure, and depending on the state of consciousness, each of these levels is able to come to the fore. Based on researches and experiments with psychedelic substances (mainly with diethylamide of lysergic acid, LSD), S. Grof came to the description of two types of consciousness heilotropic (usual) and holotropic (unusual). The first, hylotropic (from the Greek hyle, "matter", and trepein, "to move towards something") implies knowledge of oneself as an embodied physical being with clear boundaries and a limited sensory range that lives in three-dimensional space and linear time in the world of material objects", that is, what is commonly called "ordinary", "normal”, unchanged state of consciousness. The holotropic consciousness (from the Greek holos - the whole) implies a "field of consciousness without certain boundaries, which has unlimited, experienced access to various aspects of reality without the means of the senses 8 ", it is characterized by a set of representations opposite to the hylotropic consciousness.

Tarte had also formulated the idea that the assessment of the state of consciousness depends, first of all, on the value orientations of culture and the worldviews of man. In the twentieth century, when large-scale studies of altered states of consciousness originated, the Newton-Cartesian mechanistic paradigm dominated Western culture, which in many respects predetermined the attitude of Western specialists in the field of psychiatry to various kinds of altered states of consciousness. The "normal" state was therefore considered to be rational, perceptual, and cognitive with the mechanistic outlook, and any mismatch or deviation was seen as a sign of the pathological process. Therefore, mystical, religious experiences, psychedelic experiments, as well as other forms of altered states of consciousness was considered a manifestation of psychopathology. However, it has already been said that the very term of the changed states of consciousness implies the presence of some "normal" state of consciousness, in relation to which the changed state consciousness suppose turns out to be a deviation from the norm. Explaining the changed states of consciousness without comparison with the normal state seems impossible - why then they are generally called "altered"?

Thus, on the basis of the concepts analyzed in this section the classical definition of changed states of consciousness, the terms

${ }^{8}$ Гроф С. За пределами мозга. Рождение, смерть и транцсенденция в психотерапии. Москва : "Ipraktik", 2014. 504 c. URL: http://www.e-reading.club/book.php?book=98083(дата звернення: 12.05.2019). 
"transpersonal states" and "holotropic consciousness" - it becomes possible to formulate a new definition of "normal" state of consciousness. Under the normal state of consciousness will be understood the state of human consciousness, which preserves the usual (ordinary, most of the time) for a particular individual feelings of empirical individuality, individual characteristics and limitations of consciousness, are aware of physical and mental constraints. Consequently, the state in which any of these conditions is changed will be called a changed state of consciousness. This definition is in many respects correlated with the notion of a discrete, changed state of consciousness (see above), that is, any new state in relation to the original state.

Foresaid makes it possible to formulate such an understanding of the term of the changed states of consciousness that can be used to classify states of consciousness irrespective of the cultural environment and value orientations of the societies surveyed and their practices, which is extremely necessary for the full disclosure of the topic. Under the changed state of consciousness will be understood a condition in which the usual (ordinary, overwhelming majority of time) changes for a particular individual feelings of empirical individuality, individual features and limitation of consciousness, violated awareness of physical and mental constraints. Further in this work, the term "changed states of consciousness" will be used only in the above sense.

Now, we will analyze the degree of study in modern researches of the concept of "worldviews". Some domestic researchers also use the term "outlook" in their work, and even to some extent describe it, but in these works, finding the exact definition is not possible. For example, Y. Shajgorodsky in his work "Worldview Systems: the Need for Synthesis" does not share such concepts as "outlook" and "ideological systems", and moreover reduces these terms to the notion of a system of values established in a particular cultural environment ${ }^{9}$ Works by Tsvirkun V.M. world-views are a "constant, stabilizing link of human worldview ... they play a decisive role in the ideological position of the individual ${ }^{10 \text { ". }}$ He also describes them as "an experienced and conscious state of being, an active attitude toward the world ... one of the most essential elements of the worldview, consciousness of the person ... they are the basic factor of its development and

9 Шварц Т. Ю. Потребность в ощущениях : о диагностической состоятельности методики М. Цукермана. Scientific e-journal. 2016. №2. С. 188-198.

${ }^{10}$ Цвіркун В. М. Формування світоглядних установок особи підліткового віку : автореф. дис. ... канд. філос. наук : 09.00.04 «Філософська антропологія, філософія культури». Київ, 2001.25 с. 
realization, essentially determine the place of ideological consciousness in the system of human worldview ${ }^{10}$ ". That is, he describes the degree of significance that worldview facilities have for a person, for his views on the world and itmself.

Or, for example, according to a national researcher P.Ya. Makotun, ideological installations "direct the life-long activity of the individual, give it energy impulses ... they are a factor in the development and improvement of the human culture ... ["worldviews"] defines outlook stereotypes or paradigms that, in turn, affect the whole semantic coloration the life of most people ${ }^{11,}$. He describes that the worldview setting is the determining factor of the worldview, its meaningful content, but they are described only one of the characteristics of this complex term, although an attempt is made to describe this concept.

What then should be understood under "worldview settings", which definition of this concept? It should start from the analysis of the components of this concept.

Thus, the worldview is a system of views on the world and the place of man, society and mankind in it, on the attitude of man to the world and himself, as well as the corresponding attitudes of people to these basic attitudes of people, their ideals, principles of activity, value orientations $^{12}$. That is, the worldview determines how a person perceives the surrounding world and relates to it. However, the worldview is not only the content of the views on reality, but also, which is very important, acts as a "way of understanding reality", as well as the principles of life, defining the nature of determinants of attitude towards the world, behavior in the world, and life in general. It defines what is essential, for the individual, "self-consciousness of the person, its value orien-

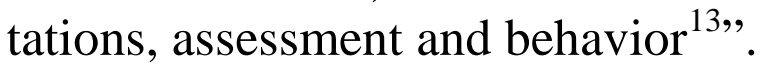

The emergence of the worldviews is gradually increasing as the individual. It is formed initially in the form of subjectively unconscious practical social relations that embody feelings, desires, aspirations, and inducements. Later, on the basis of initial experience, under the influence of education and received practical training, it is transformed into a certain

${ }^{11}$ Макутон П. Я. Світоглядні ідеали і цінності, їх місце і роль в культурі. Актуальні проблеми духовності : збірник наукових праць. Криворізький державний пед. університет. Кривий Ріг : I.B.I., 2002. C. 19-29.

12 Мировоззрение . Философия: Энциклопедический словарь / Под ред. А.А. Ивина. Москва : Гардарики, 2004. URL: https://dic.academic.ru/dic.nsf/enc_philosophy/728/MИРОВОЗЗРЕНИЕ (дата звернення: 18.05.2019).

${ }^{13}$ Мировоззрение. Новейший философский словарь / Гл. ред. : А.А. Грицанов. Минск : Книжный Дом. 1999. URL: https://psychology.academic.ru/1197/мировоззрение (дата звернення: 18.05.2019). 
internal scheme, structure of behavior, and at this level the worldview is already partly objectively defined. In young and adolescence period, based on the inner need for self-determination ${ }^{14}$, the world is shaped through the sphere of reflection, self-consciousness and introspection that complement the ideals, principles, goals and values of the ideological system. That is, the period of youth $\left(18-23\right.$ years $\left.{ }^{15}\right)$ is the stage at which the most important components of it are formed in the worldview, and from

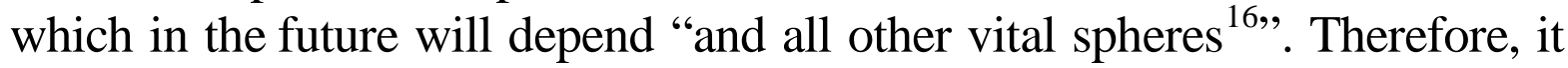
is precisely this age range that will be most interesting for research within this work, and it is from this that we will rely on the selection of a sample based on age characteristics.

At the final level of formation of this system, the worldview acts as an internal "law of life", and becomes a factor that determines the behavior of the individual as a subjective phenomenon, established as a result of the process of obtaining experience, knowledge of themselves and the surrounding reality.

From above, it naturally follows from the fact that the world goes through some stages in its formation, and that at each stage it is formed, mainly on the basis of the received social and practical experience, as well as through reflection and self-knowledge.

If we summarize the above, then the main thing in determining the outlook is that, firstly, it represents a system of views on the world around, man and society; and secondly, that these are also the ideals, values and man's settings, as well as the principles that determine his activities; and, thirdly, that it is determined, first of all, by experience.

Now that the concept of "worldview" is set, it is necessary to determine the meaning of the term "settings".

Thus, the setting (English Attitudes) is the state of readiness, the predisposition of the subject to a certain activity in a particular situation $^{17}$, which occurs at the moment of prediction by the subject of the emergence of a particular object or action, and which ensures the focus of activity on this object. The term "settings" was originally introduced into the experimental psychology by the German psychologist

\footnotetext{
14 Божович Л.И. Личность и ее формирование в детском возрасте. Санкт-Петербург : Питер, 2008. $398 \mathrm{c}$

${ }^{15}$ Сапогова Е.Е. Психология развития человека. Москва : Аспектпресс, 2005. 460 с.

${ }^{16}$ Хилько М.Е., Ткачева М.С. Возрастная психология : краткий курс лекций. 2-е изд., перераб. и доп. Москва : Издательство Юрайт, 2014. 200 с.

${ }^{17}$ Установка . Философский энизиклопедический словарь / Гл. редакция: Л. Ф. Ильичёв, П. Н. Федосеев, С. М. Ковалёв, В. Г. Панов.Москва: Советская энциклопедия, 1983. URL: https://dic.academic.ru/ dic.nsf/enc_philosophy/3536/УСТАНОВКА (дата звернення: 22.05. 2019).
} 
L. Langhe and marked the past experience of readiness to act in a certain way, determining the speed of reaction to the situation ${ }^{18}$. According to the Georgian psychologist D. Uznadze, the creator of the theory of settings, settings accumulate the existing experience, and, through the mediation of the influence of conditions of external reality, the balance between the subject and the environment ${ }^{19}$. For him, the settings an unconscious readiness of the subject to perceive future events and actions in a certain direction. Later, the study of social systems, that is, the "subjective relations of the personality to the conditions of activity ${ }^{20,}$, the Sovie (Sh. Nadirashvili, I. Gomelaura) and American psychologists (F. Hayder, L. Festusinger) led to the discovery of the structure of settings, which contains emotional, semantic and behavioral aspects of readiness for perception and action in relation to social objects and situations.

Semantic settings - this is the most "complex" level of settings, as it contains several components that determine how the worldview, and the views of the individual, and its activities. Thus, the information component contains in itself the views on the world and the place of man in it, its orientation; the emotional component includes sympathy and antipathy for meaningful objects; and behavioral determines readiness for activity. Semantic settings and settings as a whole also include value orientations, which are conditioned by the higher social needs of the subject, its activities, as well as in the process of acceding to the system of norms and values of the social environment.

Based on the foregoing, one can conclude that the settings are not only the readiness and the willingness to act, but also some essential psychic components of the subject, such as views, orientation and value orientations, which act as determinative readiness for action of factors. In the works of the national researcher V.M. Cvirkun, refers to this understanding of the installation - "they are one of the most persistent elements of the outlook of the individual, expressing itself, its inner conscious and subconscious” I “... outside the settings find expression in a

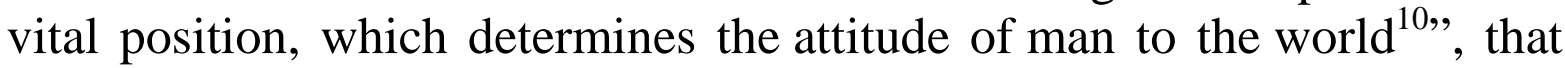
is, they define the relationship "man - the world of man".

\footnotetext{
18 Установка. Краткий психологический словарь / Под ред. Л.А. Карпенко, А.В. Петровский, М.Г. Ярошевский. Ростов-на-Дону: ФЕНИКС, 1998. URL: https://psychology.academic.ru/2731/установка (дата звернення: 22.05. 2019).

${ }^{19}$ Узнадзе Д. Н. Психология установки. Санкт-Петербург : Питер, 2001. 416 с.

${ }^{20}$ Надирашвили Ш.А. Понятие установки в общей и социальной психологии. Тбилиси: Мецниереба, 1974. 170 с.
} 
It is also necessary to point out that the existence of settings in one way or another is foreseen by the worldviews, since the latter is a determinant of the totality of social behavior (through the corresponding ideals, norms, principles, values), and, therefore, at least in part, determines readiness for action. From this we can conclude that the worldview and the settings, since both phenomena, a) are the determinants of the behavior and behavior of the subject, b) include a system of values, and c) contain an information component, are related concepts, and to some extent have in mind one another. That is, the worldview and the a settings form a rather close conceptual terminological interweaving, which can be subjected to a common denominator by combining them in the concept of "worldview settings".

Thus, such a definition is a generalized notion of concepts of "worldview" and the concept of "settings", and in the most general form can be defined in this way. Worldview devices - is a system of views of the subject to the world, the place of man in it, its orientation, attitude towards the world, consisting of the information, value and behavioral components, determines activity through these components, based on experience, social interaction, practical activity and reflection, and includes a system of norms, values, orientations, ideals, principles, goals. This definition is a generalized combination of notions of the concepts of "worldview" and "settings", and in the context of this work allows to accurately characterize and cover the range of psychic phenomena that are subject to research in this work.

\section{Modified states of consciousness as an experience that influences the worldview}

As already mentioned above,worldview systems are formed on the basis of experience. Since the very early childhood, it has a direct influence initially on the shaping of worldview settings of , and later on their faceting and more concrete and practically applicable vision of the world. Moreover, this experience is always different genesis and can be both objective and subjectively conditioned, that is, it proceeds exclusively from the outside world or is formed on the basis of introspection, reflection. The first experience of social relations, upbringing, practical learning, maturing, and later acquaintance with cultural traditions, one's own activity - all this directly influences the formation of a concrete world view, which ultimately determines behavior in the form of ideals and norms. But here is the main question, 
the answer to which is intended to serve this work - is it possible to include in this list of factors that influence and shape worldview settings, include the experience of staying in the changed states of consciousness?

A unambiguous and definite answer can only be obtained by deepening into empirical data, but before doing this, it is necessary to identify - perhaps descriptions of the cases of influencing the experience of changed states of consciousness on worldview have already been found in the literature?

Therefore, to answer the question, one must refer to one of the most studied forms of altered states of consciousness, namely, changes in the state of consciousness induced by the administration of psychedelic substances (LSD, psilocybin, dimethyltriptamine. First of all, we will consider a wide range of experiences in the LSD sessions described by the transpersonal psychologist S. Grof $\mathrm{f}$ in his works devoted to LSD experiments.

S. Grof 's research is based on more than three thousand LSD sessions personally conducted by him, and more than five thousand reports of sessions he studied ${ }^{21}$. Such a significant amount of processed empirical material allows us to speak about the high significance and value of research data.

Of the four types of experiences encountered in LSD sessions, the greatest interest for us is the third - perinatal experiences - since they, according to S. Grof, have the greatest impact on the human psyche and have long-term effects.

Perinatal experiences are the experiences induced both by psychoactive substances and non-medicated means (S. Grof mentions, for example, trance dancing, starvation, shock, physical torture, sleep deprivation, and well-worked spiritual practices), which "are focused on the problems of biological birth, physical pain and agony of aging, diseases and aging, as well as dying and death". These experiences are of ten encountered in experiments using high doses of LSD, and may be detected even at the first sessions ${ }^{22}$.

Since this level includes a very wide range of experiences, S. Grof of fers a special classification, which is based on the analogy with the stages of human birth (which comes from the presence of deep parallels between patterns of experiences and clinical stages of childbirth).

${ }^{21}$ Гроф, С. ЛСД психотерапия / Пер. с англ. Г. Васильевич. Москва : «Издательство АСТ», 2004. 414 c.

${ }^{22}$ Гроф С. Области человеческого бессознательного: данные исследований лСД. Киев: PSYLIB, 2003. $278 \mathrm{c}$. 
It identifies four Basic Perinatal Matrices (BPMs) that correspond to: I-finding the child in the womb, II-the beginning of labor, III-pushing through the birth canal, and IV-completing the birth process. We are primarily interested in the II, III and IV BMDs, since it is in them that the eschatological motive is clearly expressed. However, before switching to the description of experiences in the BPM, it should be noted that visions and feelings are experienced by the subjects extremely realistic of ten they lose the understanding that all experiences are only an illusion, and confuse their feelings with true biological death. This point needs to be taken into account in order to understand the high significance and impact that such experiences have on the patient's future life.

It is important to note that the experiences experienced by the subjects relate not only to their usual picture of the world and their known ideas, but also to the previously unknown scenarios. In works by S. Grof, descriptions of such cases occur quite of ten: "It happened", he writes, "that inexperienced people described in detail the stories from the Hindu, Buddhist, and Jainist mythologies, or the multi-layered scenes from the little-known” Egyptian Book of the Dead ${ }^{23 ” . ~ I t ~ i s ~ a l s o ~}$ important to note the fact that it is extremely important for us that such experiences can be caused not only by psychoactive substances, but also by non-medicated means, for example, holotropic breathing - a special technique of controlled breathing, which by means of hyperventilation introduces a person into a very deep ICS which is not inferior in intensity and strength of the influence of altered states of consciousness induced by psychedelics.

In many cases, such experiences have a significant impact on the future life and worldview of a person. First of all, the experience of death-rebirth has a prof ound catharsis and psychotherapeutic effect, which manifests itself not only in the potential treatment of mental illness (recall that transpersonal psychology considers mental illness as a "transpersonal crisis" caused by the conflict of the unworked unconscious material and consciousness), but also in changing the value orientations and attitudes of healthy people. This effect is echoed by the influence of deathregeneration on medicine-man as a result of initiation ceremonies, and on participants in ancient Greek mysteries. Second, the lifestyle and human worldview undergo prof ound changes based on the full realization of their mortality and on the belief in the possibility of the existence

${ }^{23}$ Гроф С., Хэлифакс Дж. Человек перед лицом смерти / Пер. с англ. А. И. Неклесс. Москва : Изд-во Трансперсонального Института, 1996. 246 с. 
of consciousness after physical death. Based on the experiences of the test subjects, they form the following notions about life after death that they never had before: "Even positivist-oriented scholars, convinced materialists, skeptics and cynics, uncompromising atheists ... are of ten beginning to be interested in spiritual searches after they discovered inside themselves these levels ${ }^{25}$ ". And according to V.M. Cvirkun, worldviews "are formed and fixed in the process of the in the process of man's active resolution of cardinal problems of being, the identification of the worldview of the essence of human life, the definition of life meaningful landmarks in the dialogue of a person with the world in which it lives ${ }^{10,}$. Such a cardinal problem of being is quite possible to consider the views of life after death or death itself, that is, one can assume that such deep feelings can in some way form a world outlook.

The above data allow us to suggest that the experience of altered states of consciousness can have some influence on a person's perception of the world, of itmself, of its values, ideals, norms and views, and, in general, on ideological systems. And if so, then it is quite logical that differences in the ideological setting between people who have such experience of experience of altered states of consciousness and people who do not have such an experience can be detected. In general, this assumption, this hypothesis that the worldview settings of people with experience and without the experience trial altered states of consciousness have differences and serves as the main hypothesis of this work, which in the future and will be checked by conducting an empirical study.

Thus, we can draw the following conclusions. The views of man on the world and its attitude to it largely depend on the fact that man knows about the world, that this world is. And this kind of knowledge can be discovered by a person not only from the pages of textbooks, academic education or field trials, but also to a large extent they are formed by observations that the individual consciously or unconsciously does in its life's way. These observations can be as external - the objective world surrounding the person - and exclusively internal - from simple reflection and ending with the "sphere of the spiritual", the comprehension of the individual and collective unconscious, if you reason within the terminology of K. Jung and C. Grof . Experience largely determines the ideological orientation of man,its orientation, values, norms and ideals, which in the future determine the activity. And in this case, the experience of direct interaction with the sphere of the spiritual, as well as any other experience, must have a definite influence on worldview. 


\section{CONCLUSIONS}

The analysis of the literature on the topic was carried out, the concepts of "consciousness", "changed states of consciousness" and "world outlook" were considered and analyzed. In the case of the term "changed states of consciousness", on the basis of already existing definitions was synthesized and proposed a new definition that more accurately describes the range of experiences that we understand as changed states of consciousness. Under the changed state of consciousness is meant a state in which the usual (ordinary, overwhelming majority of time) changes for a particular individual feelings of empirical individuality, individual characteristics and limitation of consciousness, disturbed awareness of physical and mental constraints

In addition, since the exact interpretation of the term "worldview" in the special literature on the topic was not revealed, from the concepts of "worldview" and "settings" was identified definition of "worldview settings": worldview settings - is a system of views of the subject to the world, the place of man in it, its orientation, attitude towards the world, consisting of the informational, value and behavioral components that determines activity through the data-based components of experience, social interaction, practice and ref lexis, and includes a system of norms, values, orientations, ideals, principles, goals. The main characteristics of ideological settings were also highlighted and described.

\section{SUMMARY}

The analysis of the literature on the problem of the influence of changed states of consciousness on the formation of worldview settings allowed to formulate the hypothesis of the existence of a statistically significant difference in the worldview settings of people with the experience of changed states of consciousness and without such experience. The basic preconditions are based on the experiments of the representative of the transpersonal psychology of S. Grof and are reduced to the fact that in the scientific literature there are cases where the practice of experiencing altered states of consciousness had an effect on the change in the views, interests, beliefs, ideals, norms of people.

The study of the concepts of "changed states of consciousness" always correlates with the notions of the "normal" state of consciousness, which, on the basis of existing terms (the classical definition of changed states of consciousness, the term "transpersonal states" and "holotropic consciousness"), was defined as such a state 
of human consciousness, which preserves the usual (ordinary, most of the time) for a particular individual feelings of empirical individuality, individual features and limitations of consciousness, are perceived as physical and psychic constraints. Proceeding from this, the new definition of "changed state of consciousness" is formulated - this is a state in which the usual (ordinary, overwhelming majority of time) changes for a particular individual feelings of empirical individuality, individual features and limitation of consciousness, disturbed awareness of physical and mental constraints. Since the exact interpretation of the term "worldview settings" in the literature on the topic was not found, from the concepts of "worldview" and "settings" was highlighted the following definition of worldview settings: worldviews - a system of views of the subject to the world around it, to the place of man in it, its orientation, attitude towards the world, consisting of the informational, value and behavioral forms that determines activity through these components, based on experience, social interaction, practical activity and reflection, and includes a system of norms, values, orientations, ideals, principles and objectives.

\section{REFERENCES}

1. United Nations Of fice on Drugs and Crime. World Drug Report 2016. SalesNo. E.16.XI.7. New York : United Nations publication, 2016. 174 p. URL:http://www.unodc.org/doc/wdr2016/WORLD_DRUG_ REPORT_2016_web.pdf. (дата звернення: 12.05.2019).

2. Кулешов Р.Н. Виртуальная реальность компьютерных игр как феномен ИСС. Психотехники и измененные состояния сознания / Отв. ред. С. В. Пахомов. Санкт-Петербург : РХГА, 2015. URL:http://www.yoga.net.ua/filials.php?action=shownews\&id=1421\& fid=34 (дата звернення: 12.05.2019).

3. Леонтьев А.Н. Эволюция психики. Воронеж : Издательство НПО «МОДЭК», 1999. $416 \mathrm{c.}$

4. Тарт Ч. Измененные состояния сознания. Ульяновск : «Ульяновский Дом Печати», 2003. 537 с.

5. Психология сознания / Сост. и общая редакция Л. В. Куликова. Санкт-Петербург : Питер, 2001. 480 с.

6. Спивак Д.Л. Изменённые состояния сознания: психология и лингвистика. Санкт-Петербург : «Издательский Дом Ювента»; Филологический ф-т СПбГУ, 2000. 296 с. 
7. Тарт Ч. Системный подход к сознанию. Пути за предель эго / Под ред. Р. Уолша и Ф. Воон. Москва : Открытый Мир, 1996. URL: http://www.klex.ru/7wt (дата звернення: 12.05.2019).

8. Гроф С. За пределами мозга. Рождение, смерть и трансценденция в психотерапии. Москва : "Ipraktik", 2014. 504 c. URL: http://www.e-reading.club/book.php?book=98083 (дата звернення: 12.05.2019).

9. Шварц Т. Ю. Потребность в ощущениях : о диагностической состоятельности методики М. Цукермана. Scientific e-journal. 2016. № 2. C. $188-198$.

10. Цвіркун В. М. Формування світоглядних установок особи підліткового віку : автореф. дис. ... канд. філос. наук : 09.00.04 «Філософська антропологія, філософія культури». Київ, 2001. 25 с.

11. Макутон П. Я. Світоглядні ідеали і цінності, їх місце і роль в культурі. Актуальні проблеми духовності : збірник наукових пращь. Криворізький державний пед. університет. Кривий Ріг : I.B.I., 2002. С. 19-29.

12. Мировоззрение . Философия: Энциклопедический словарь / Под ред. А.А. Ивина. Москва : Гардарики, 2004. URL: https://dic.academic.ru/dic.nsf/enc_philosophy/728/МИРОВОЗЗРЕНИЕ (дата звернення: 18.05.2019).

13. Мировоззрение. Новейший философский словарь / Гл. ред. : А.А. Грицанов. Минск : Книжный Дом. 1999. URL: https://psychology.academic.ru/1197/мировоззрение (дата звернення: 18.05.2019).

14. Божович Л.И. Личность и ее формирование в детском возрасте. Санкт-Петербург : Питер, 2008. 398 с.

15. Сапогова Е.Е. Психология развития человека. Москва : Аспектпресс, 2005. 460 c.

16. Хилько М.Е., Ткачева М.С. Возрастная психология : краткий курс лекций. 2-е изд., перераб. и доп. Москва : Издательство Юрайт, 2014. $200 \mathrm{c}$.

17. Установка . Философский энциклопедический словарь / Гл. редакция: Л. Ф. Ильичёв, П. Н. Федосеев, С. М. Ковалёв, В. Г. Панов. Москва: Советская энциклопедия, 1983. URL: https://dic.academic.ru/dic.nsf/enc_philosophy/3536/УCTAHOBKA (дата звернення: 22.05. 2019).

18. Установка. Краткий психологический словарь / Под ред. Л.А. Карпенко, А.В. Петровский, М. Г. Ярошевский. Ростов-на-Дону: 
ФЕНИКС, 1998. URL: https://psychology.academic.ru/2731/установка (дата звернення: 22.05. 2019).

19. Узнадзе Д. Н. Психология установки. Санкт-Петербург : Питер, 2001. 416 с.

20. Надирашвили Ш.А. Понятие установки в общей и социальной психологии. Тбилиси: Мецниереба, 1974. 170 с.

21. Гроф, С. ЛСД психотерапия / Пер. с англ. Г. Васильевич. Москва : «Издательство АСТ», 2004. 414 с.

22. Гроф С. Области человеческого бессознательного: данные исследований ЛСД. Киев: PSYLIB, 2003. 278 с.

23. Гроф С., Хэлифакс Дж. Человек перед лицом смерти / Пер. с англ. А. И. Неклесс. Москва : Изд-во Трансперсонального Института, 1996. 246 с.

\section{Information about the authors:} Kononenko O. I.,

DrSc of Psychology, Professor at the Department of Differential and Special Psychology of the Odessa I. I. Mechnikov National University 15/13, Tenistaya str., Odesa, 65009, Ukraine

Shandruk S. K.,

Doctor of Psychology, Professor, Deputy Head of the Curriculum and Instruction Department, Professor at the Department of Psychology and Social Work, Ternopil National Economic University 